\title{
Founding Economy on Quality Science Assessment Edification: The Ultimate Brain Power
}

\section{Akbar Nikkhah*}

Chief Highly Distinguished Professor, Department of Animal Sciences, Faculty of Agricultural Sciences, University of Zanjan, Iran

\begin{abstract}
Summary
This article develops a pragmatic theory of global-national nature that founds economy on science education and assessment quality as the postmodern brain power. Should be built on well-established science and technology education and evaluation in schools, universities and other skill-training institutions, the economy will not encounter dramatic fluctuations in its growth and expansion.
\end{abstract}

Keywords: Science education; Economy; Brain power

\section{Theory Formulation and Discussion}

In essence, management is a foremost science and practice in any life discipline. Global and national management of science education both quantitatively and qualitatively determines how effective and efficient humans utilize natural and artificial resources in enhancing life understanding and quality [1-4]. Briefly put, science and technology education must be managed delicately and robustly in academia and industry to ensure building an economy that can dynamically grow and resist against unexpected unavoidable risks that impose crisis [5-7].

For science education to be economy-yielding, quality standards in science evaluation and optimization must be developed and practiced. Over the recent years, unfortunately, credentialism (giving value to academic degrees and documents per se without evaluating the principal qualities) has grown substantially in both academia and society. As a result, in many cases, not all degree owners deserve the degree they hold. This academic crisis stems mainly from substandard evaluation systems in science and industry institutions. Overvaluing memorizing capacities and overlooking pragmatic elite-creating and challenge-dealing capabilities are among academic disasters that ruin national and indeed the world economy [8-10]. Negligence in quality assessment of science mentees will result in inheritance of such a futile policy to next generations, which very quickly demolishes the economy. This is mainly due to generating unqualified superficial degree holders that are not only incapable of conducting their presumed expertise optimally but they are also unable to inspire and manage others [911]. Such an educational corruption is extendable to the entire society should rashness in science education quality assessment become a phenomenon.

\section{Implication}

In a nutshell, shaping an influential wealthy social economy that can be expressed in any individual's life requires quality management of science and technology education and evaluation. This is the ultimate pathway to guarantee dynamic growth in global, continental, national, provincial, social, family and individual economies.

\section{Acknowledgment}

Thanks to Iran's Ministry of Science Research and Technology, National Elite Foundation, University of Tehran, Isfahan University of Technology and University of Zanjan for supporting the author's global programs of optimizing science edification in the third millennium.

\section{References}

1. Nikkhah A (2015) The Elite-Creation Art (In Persian). Jahad-e-Daneshgah Publishing Organization, Iran.

2. Nikkhah A (2012) Elite science education arts of the new millennium. LAP LAMBERT Publishing, Germany.

3. Nikkhah A (2015) Global Science Education: Bioprocessing and Brainfueling of Innovation. J Bioprocess Biotechniq.

4. Nikkhah A (2014) Boosting National Economy by Challenging International Education. Journal of Global Economics.

5. Nikkhah A (2014) Green Economy through Edification: Quality Life through Arts. J Glob Econ.

6. Nikkhah A (2014) Timely Economy Evolution via Moral Science Edification. Journal of Global Economics.

7. Nikkhah A (2014) Science of the new times: A circle not a line. Adv Crop Sci Technol.

8. Nikkhah A (2013) Science Edification Arts: The Ultimate Frontiers to Eradicate Economic Sanctions. The Open Access Journal of Resistive Economics 1: 1-6.

9. Nikkhah M, Nikkhah A (2011) Optimizing Academic Education: Philosophies for Creative Quality Lives 2: 458-460.

10. Nikkhah A (2011) Postmodern Science Edification Philosophy. Open Journal of Philosophy 1: 37-38.

11. Weinberg S (2011) Nobelist Steven Weinberg Calls for Bigger Science, More Taxes. World Science Festival, New York, USA.
*Corresponding author: Akbar Nikkhah, Chief Highly Distinguished Professor, Department of Animal Sciences, Faculty of Agricultural Sciences, University of Zanjan, Iran, Tel: +98 (24) 33051; E mail: anikkha@yahoo.com

Received May 09, 2015; Accepted May 15, 2015; Published May 22, 2015

Citation: Nikkhah A (2015) Founding Economy on Quality Science Assessment Edification: The Ultimate Brain Power. J Glob Econ 3: e108. doi:10.4172/2375$4389.1000 \mathrm{e} 108$

Copyright: $\odot 2015$ Nikkhah A. This is an open-access article distributed under the terms of the Creative Commons Attribution License, which permits unrestricted use, distribution, and reproduction in any medium, provided the original author and source are credited. 